\title{
473. RF組織内加温の基礎的研究及び臨床応用への考察
}

RF Interstitial hyperthermia,fundamental experiments for clinical applications

東京慈恵会医科大学 放射線科

○望月 真 永井 均 木村 義人 成田 浩人 堀内 英幸 鈴木 久栄 M.Mochizuki H.Nagai Y.Kimura H.Narita H.Horiuchi H.Suzuki

【目的】

今回我々は、円盤状外部電極と複数の針電極を刘電極とした、RF組織内加温を試みた。 基礎実験を通して本RF組織内加温法について検討し、臨床応用に向けて考察し報告する。 【使用機器及び原理】

今回使筩した、寻ムロン社製組織内加温試作装置HEH-50は $13.56 \mathrm{MH}$ z RFを用い誘電加温方式を加温原理とし、最大出力 は50Wまで出力可能である。(写真 1)

外部電極はHEH-500Cと共用の直径 $10 \mathrm{c} \mathrm{m}$ の平以盤状電極を 使用し針電極は直径 $0.8 \mathrm{~mm}$ 長さ $10 \mathrm{c} \mathrm{m}$ のステンレス製で 表面を金で被覆している。コネク多部は $5 \mathrm{~mm}$ 間隔で針電極を 5本まで並列接続が可能である。(写真 2)

その他の周辺機器として、銅-コシスタンタン熱電対温度計 並びに情報收集筩パソコシはHEH-500Cと共用である。 加温対象を 8〜 13.56MHz用標準筋肉等価寒天ファントームとし 2つの寒天ファントームに針電極を挟み外部電極により加温し 断面の温度分布をサーモグラフィーに記録した。温度測定は 銅ーヨンスタンタン熱電対温度計を使用し針電極の先端部 同中央部、同中央部直下 $5 \mathrm{~mm}$ 、同中央部直下 $1 \mathrm{c}$ m 9 以上 4点を測定点とした。尚、得られた温度分布がSAR分布に 近似するよう考慮し 各測定点の温度上昇率を測定し温度分布 を检討した結果、今回の実験では、針電極中央部直下 1 c m 測定点が $3^{\circ} \mathrm{C}$ 上昇した時点に扔ける温度分布を評価する こととした。(写真 3)

【方 法】

(実験 1) 絶縁用外筒装着による、有効加温長の調節を試みた。 絶緣用外筒は19Gアンギオカッ夕ーの仆筒を使用し、加温方法は 針電極間隔を $5 \mathrm{~mm}$ 5本並列にて、外部電極と平行に、加温条件を 30Wとして加温した。

(実験 2) 針電極と外部電極の位置関係が温度分布に及ほす 影響について調べた。加温条件を実験 1 と同様にして針電極 の位置を針電極の先端方向、針電極左右側方向、針電極の 後尾部方向からそれぞれ加温した。

【結部集】

結果 1$)$ 有効加温長の調節は, $2 \sim 7 \mathrm{c} \mathrm{m}$ の範囲で調節可能

であった。(写真 4) 一方、有効加温長が7.5 c m以上に なると加温領域内で高加温領域が針電極先端部に移動する 傾高があった。

(結果2) 電極の位置関係が温度分布に及ぼす影響と しては加温領域は変化がないが、高加温領域が外部電極 の加温方向に移動する倾向にあった。又後尾部方向から の加温時のみ、 $0.3 \sim 0.5^{\circ} \mathrm{C} / \mathrm{min}$ 程度の温度上昇率の低下

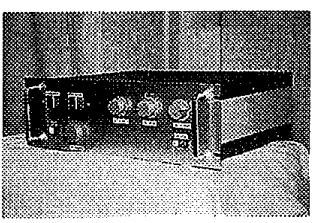

写真1. HEH-50本体部

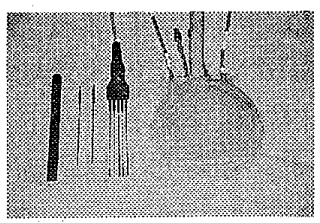

写真2.外部電極及び 針電極

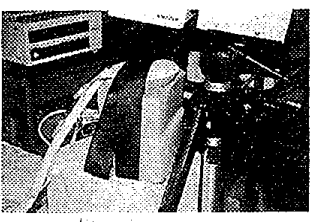

写真3.加温実験

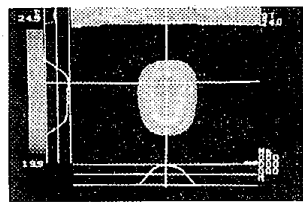

写真4. 有効加温長 $5 \mathrm{c} \mathrm{m}$ の温度分布 を哂め繁】

有効加温長を簡便に調節出来ると言う事は、臨床応用上，腫瘍の形状に応じた加温領域 を任意に設定卞る事が出来ると考えている。次に針電極の刺入方向に对してどの方向から でも加温が可能であると言う点も臨床応用上大な利点と言えよう。しかし、有効加 温長の調節に限界がある点、高高加温領域が外部電極の加温方高に移動する傾向について は今後の課題として実験を進めて行きたい。


能を低下させる事なく、針電極の増設、発生器の高出力化等の改良を今後の課題とし、現

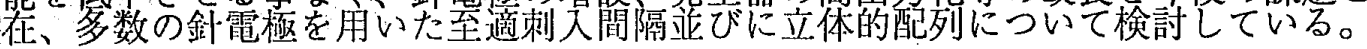

